\title{
ОБЗОР ГЕНЕТИЧЕСКИХ ОСНОВ ФОРМИРОВАНИЯ ДЕВИАНТНОГО ПОВЕДЕНИЯ
}

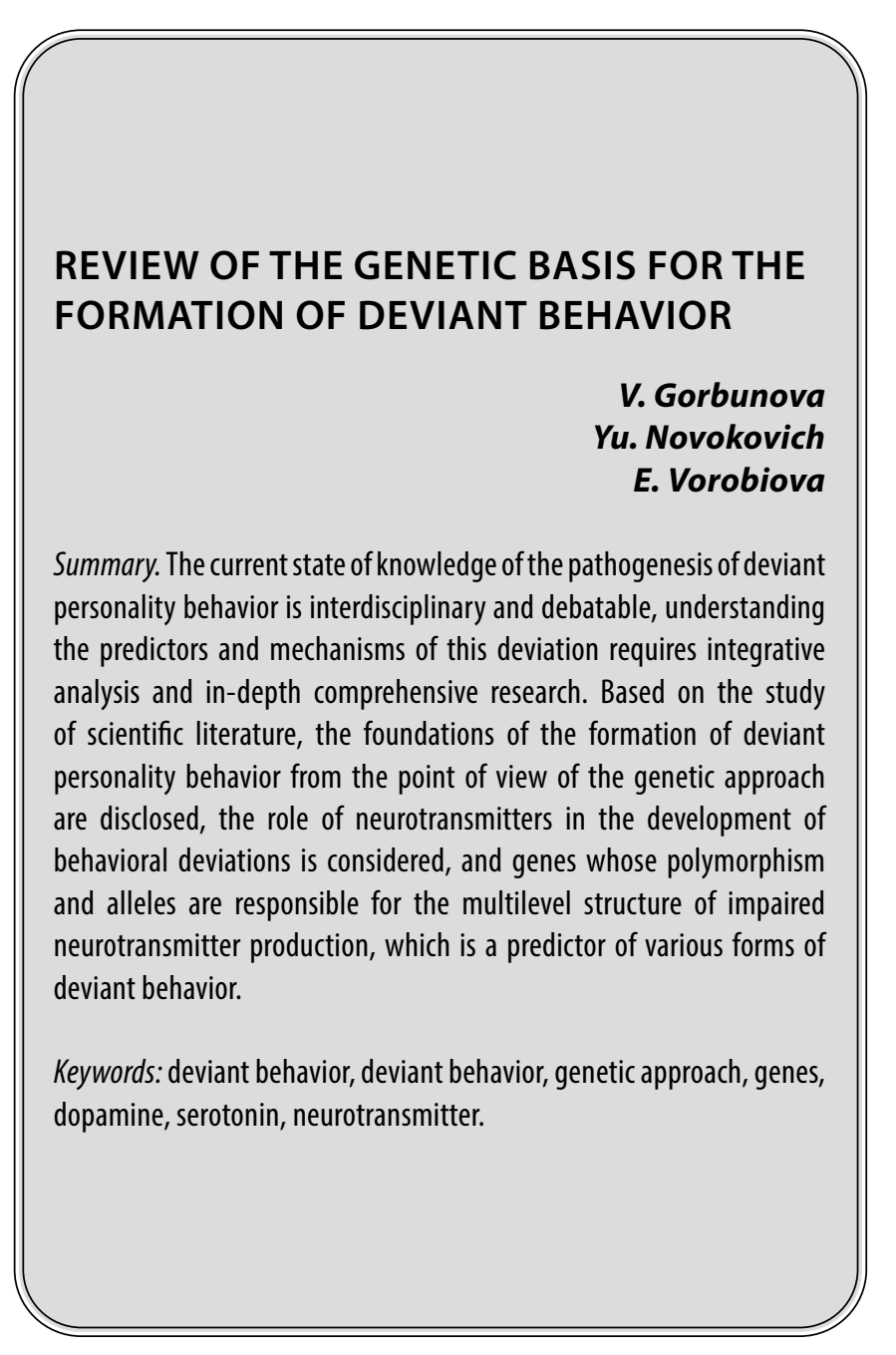

\section{Введение}

$\Pi$ оведением называется активность живых организмов, которая обеспечивает их приспособление к окружающей среде и удовлетворение жизненных потребностей. Поведение человека, в отличие от животных, всегда социально обусловлено и имеет сознательный, целенаправленный характер. Человек направляет свои действия не только на удовлетворение потребностей, но и на организацию взаимоотношений с другими людьми в общественно принятых нормах морали и права. Девиантным поведением являются действия человека, которые нарушают официально установленные в обществе или неофициально признанные в определенной социальной группе моральные и правовые нормы. К основным видам девиантного поведе-
Горбунова Валентина Юрьевна

Д.б.н., профрессор, ФГБОУ ВО «Башкирский государственный педагогический университет им. М. Акмуллы», г. Уфра valentina2075034@mail.ru

Новокович Юлия Сергеевна Аспирант, ФГБОУ ВО «Башкирский государственный педагогический университет им. М. Акмуллы», г. Уфа novokovich@inbox.ru

Воробьева Елена Владимировна К.б.н., дочент, ФГБОУ ВО «Башкирский государственный педагогический университет им. М. Акмуллы», г. Уфра vorobeva.e.v@bspu.ru

Аннотация. Современное состояние изученности патогенеза девиантного поведения личности носит междисциплинарный и дискуссионный характер, понимание предикторов и механизмов данного отклонения требует интегративного анализа и углубленного комплексного исследования. В статье на основе изучения научной литературы раскрыты основы формирования девиантного поведения личности с точки зрения генетического подхода, рассмотрена роль нейромедиаторов в процессе развития отклонений в поведении, а также выделены гены, полиморфизм и аллели которых отвечают за многоуровневую структуру нарушения продукции нейромедиаторов, что является предиктором различных форм девиантного поведения. Особую роль в формировании девиации авторы статьи отводят гипоксии мозга.

Ключевые слова: отклоняющееся (девиантное)и поведение, девиантное поведение, генетический подход, гены, дофамин, серотонин, нейромедиатор.

ния относят преступность, аддиктивную (алкогольную, никотиновую и др.) зависимость, самоубийство и сексуальные извращения [1]. Подростки в возрасте 14-18 лет, воспитанные в неблагоприятных социальных условиях, имеющие наследственное бремя психических расстройств, токсикомании, наркомании и алкоголизма, наиболее подвержены поведенческим отклонениям [2].

Девиантное поведение интенсивно исследуется широким кругом различных отраслей науки - социологией, криминологией, медициной, генетикой, педагогикой. Развитие исследований по генетике девиантного поведения приходится на 90-е годы прошлого века. Особенно активизировались они с началом XXI в., когда для широкого круга генетиков стали доступными современные технологии молекулярной биологии - 
определение последовательностей ДНК (секвенирование) и выявление общегеномных ассоциаций.

\section{Цель статьи}

Заключается в теоретическом анализе современных представлений о генетических механизмах наиболее распространенных видов девиантного поведения.

\section{Из^ожение основного материала}

Развитие индивида имеет вероятностный характер. Существует врожденная склонность к девиациям, и она проявляется при попадании в социально неблагоприятные условия. Так, например, у геймеров часто встречается синдром дефицита внимания, который связан с нарушениями метаболизма дофамина. В основе физической наркоманийной зависимости лежат, вероятно, устойчивые биохимические изменения в организме, развивающиеся в результате регулярного и достаточно длительного употребления наркотического вещества. Химические аддикции коррелируют с повышенной активностью правого полушария, что приводит к эндогенным психическим расстройствам (шизофрения, аффективные психозы). Употребление психоактивных веществ или определенный тип поведения, по сути имеет «лечебную» причину, то есть реципрокно улучшает функцию левого полушария, что имеет кратковременный эффект «улучшения» в эмоциональной сфере, впоследствии токсическое действие психоактивных веществ приводит к угнетению обоих полушарий. Вышеупомянутые нейрохимические изменения в норме связаны с мотивацией деятельности, вознаграждения или наказания в зависимости от результата деятельности и т.д. При девиантном (например, аддиктивном) поведении эти изменения приобретают сверхценное значение и впоследствии «нормальный гомеостаз» ЦНС подменяется на «девиантный».

Так, согласно данным многочисленных исследований, проведенных в последние годы, среди генетических факторов наркомании выявлено снижение экспрессии генов определенных нейротрансмиттеров. Одни из этих гормонов (эндорфины, энкефалины), блокируя соответствующие рецепторы, вызывают нормальное настроение, другие (серотонин) - обеспечивают нормальную воображение, наличие в сознании необходимых ценностей, радостных событий в жизни и вообще смысла жизни. Если таких гормонов вырабатывается недостаточно вследствие мутаций или снижения экспрессии соответствующих генов, это вызывает психический и физический дискомфорт, поиск средств и веществ, которые бы могли его устранить [3].

При этом мозг является аэробным органом, требует около $20 \%$ от общего потребления кислорода у человека. В особо чувствительных структурах мозга, например, в коре больших полушарий, вследствие воздействия гипоксии изменяется нормальный баланс нейромедиаторов (глутамата, дофамина, серотонина, ацетилхолина и др.) и продуктов их обмена. Реакции организма человека на различные виды гипоксии широко варьируют и запускаются независимыми внутриклеточными молекулярными механизмами [4]. За период 1977-2019 годов исследователи провели большую работу по изучению механизмов адаптации к гипоксии, ее повреждающим эффектам и генетическим предикторами развития осложнений гипоксии. Лауреаты Нобелевской премии 2019 года по медицине Уильям Кэлин, Грегг Семензе и Питер Рэтклифф обнаружили генетический механизм, который позволяет организму регулировать уровни кислорода в разных частях тела и управлять ими [5].

Исследования подчеркивают роль индуцибельного фактора гипоксии-1a (HIF-1a) в регуляции гипоксического ответа как в нейронах, так и в глиальных клетках [6]. Однако регуляция центральных нейромедиаторных систем недостаточно изучена в условиях гипоксии, хотя их неадекватная адаптация может способствовать развитию аномальных поведенческих паттернов у пациентов, страдающих церебральной гипоксией. Разнообразные физиологические функции серотонина опосредованы большим числом рецепторов НТ, которые кодируются различными генами. Есть не менее 15 подтипов рецепторов, принадлежащих к четырем классам рецепторов: 5-HT1/5, 5-HT2 (A, B, C), 5-HT3 и 5-HT4/6/7. 5-НТ был вовлечен в этиологию многих заболеваний, в том числе депрессия, тревога, социальная фобия, шизофрения, невроз навязчивых состояний и паническое расстройство. За синтез этого гормона отвечают многочисленные нейроны, локализующиеся в промежуточном и большом мозге. В числе прочих функций серотонин принимает участие в обеспечении регуляции общего фона настроения и беспокойства, формировании стереотипов полового и агрессивного поведения. Дефицит выработки серотонина приводит к насилию, истерии, психозам, суицидальному поведению и прочим девиантным проявлениям [7].

Исследование роли серотонинэргической системы в регуляции поведения было проведено большим числом исследователей, и в обзоре Е.М. Ковш [8] подробно описаны этапы открытий в данной области. Важными вехами явилось обнаружение влияния гена фермента биосинтеза 5-НТ-триптофангидроксилазы-2 в регуляции враждебного поведения, выявление роли 5-НТ1А рецепторов в подавлении агрессии, вызванной страхом, и агрессии нападения [9;10]; определение роли генов, ответственных в синтезе серотонина (BS6D4) и дофамина (СОМТ), роли серотонинэргической системы 
в расстройствах настроения и в предрасположенности к суицидальному поведению [11]. В работах авторов отмечено, что морфологические нарушения промотора гена BS6D4 отражаются в изменении его функциональности и ведут к изменению уровня синтеза кодируемого белка, что отражается на возникновении девиаций.

В настоящее время идентифицировано по крайней мере до 1500 генов, мутации которых могут вызвать склонность к наркомании. Это гены, которые определяют функции рецепторов, транспортеров или метаболических ферментов нейротрансмиттерных систем. В исследовании Е.В. Черепковой с коллегами среди 93 молодых людей, употребляющих наркотики, было выявлено, что частота полиморфизма 4/4 гена дофаминового рецептора 4-подтипа (DRD4) составила 80,0\%. В обычной популяции распространенность этого полиморфизма составляет - 57,9\%. Также отмечено, что полиморфизм 4/3 не встречался только у лиц без наркотической зависимости. Ген дофаминового транспортера (DAT), картированный на коротком плече хромосомы 5 (5р15.3), может рассматриваться как один из генов предрасположенности к развитию наркоманий и психических заболеваний [12].

Ген D2-рецептора дофамина (DRD2) локализуется в длинном плече хромосомы 11 в области q22.3-23.1 (11q23.2). замена аллелей С на Т приводит к нарушению регуляции экспрессии гена NF-кB и опосредованное им снижение плотности D2 рецепторов в головном мозге. У носителей А1-аллеля наблюдается 30-\% снижение плотности дофаминовых рецепторов D2 во всех участках полосатого тела и узлов, входящих в экстрапирамидную систему головного мозга [13]. Мутация гена DRD2 (11q23.2) может вызвать зависимость от кокаина, героина и злоупотребление психостимуляторами; мутация гена DAT1 (SLC6A3) (5р15.3) способна вызвать зависимость от кокаина; мутация гена СОМТ (22q11.21) - зависимость от метамфетамина, кокаина и героина; OPRM1 (6q24-q25) - зависимость от опиатов и героина. Ген фермента дофамин-бета-гидроксилазы (DBH) кодирует дофамин-бета-гидроксилазу - фермент, катализирующий реакцию синтеза норадреналина из дофамина путем $\beta$-гидроксилирования. DBH является связующим звеном двух важнейших частей катехоламиновой системы организма - дофаминэргической и норадренэргической. 444 A/G и 1021 C/T полиморфизм гена обуславливают усложненное течение алкоголизма, склонность к наркомании [14].

Не существует какого-то одного гена, который бы определял зависимость от алкоголя. В настоящее время выявлено более 50 генов риска развития алкоголизма, проявление которых в разной степени зависит от факторов окружающей среды - ситуации в семье, в кругу товарищей и обществе. Исследователи выявили две группы таких генов: гены, которые контролируют утилизацию алкоголя в организме, и гены, которые определяют нейропсихическим функции [15]. В утилизации алкоголя в организме участвуют ферменты алкоголь-дегидрогеназа и альдегид-дегидрогеназа. Первый из них кодируется группой генов Алкогольдегидрогеназы ADH, локализованной в 4-й хромосоме (4q21-q25), а второй - геном Алкогольдегидрогеназы ALDH2, локализованным в 12-й хромосоме (12q24.12). Среди генов, которые определяют нейропсихическим функции и связанные с риском алкоголизма, лучше всего изучены гены рецепторов нейротрансмиттеров - гормонов, которые принимают участие в передаче нервных импульсов между нервными клетками,- DRD2 (11q23.2), CHRM2 (7q33), OPRM1 (6q24-q25), NPY2R (4q32.1), NPY5R (4q32.2) др. Определенные мутации этих генов могут спровоцировать развитие алкоголизма. Возможна ассоциация генотипа A2/A2 (ген (DRD3) с острым алкогольным психозом у русских мужчин и башкиров старше 35 лет [16].

Связь между геном рецептора дофамина D2 (DRD2) Taq1A (rs1800497) и расстройством, связанным с употреблением алкоголя, является устойчивой, однако являлась предметом давних противоречий. Y.Jung в исследовании трех групп населения (финская, коренная американская и афроамериканская), которые были генотипированы для 208-277 информативных однонуклеотидных полиморфизмов (SNP) по всему региону DRD2, показал ассоциации SNP rs1800497в этом регионе с алкогольной зависимостью. Тем не менее, связь была обусловлена спонтанно низкими частотами аллелей в контроле в положительных исследованиях, что также объясняло некоторую гетерогенность между исследованиями [17].

Генов, которые причастны к развитию алкоголизма, много, но каждый из них в отдельности оказывает незначительное влияние. В полной мере неблагоприятная совокупность таких генов может проявиться при наличии провоцирующих факторов окружающей среды, одним из которых является неблагополучная семья. Там же, где ребенок окружен любовью и пониманием, и с воспитанием все в порядке, воздействие аномальных генов уменьшается, и их носители проявляют асоциальное поведение не чаще, чем носители нормальных генов.

Самым распространенным видом наркоманийной зависимости является вдыхание тлеющего дыма табака. К причинам популярности этой вредной привычки относятся также временная тонизирующее действие никотина, адаптация к нему организма и сила привычки. В наше время табакокурения практикует более 1,1 млрд. 
человек, что составляет около трети взрослого населения мира [18]. Генетическое влияние на пристрастие к табакокурению варьирует в широких пределах, о чем свидетельствует значительная изменчивость коэффициента унаследования этой опасной привычки - 40$80 \%$. Мужчины в большей степени склонны к развитию зависимости от курения по сравнению с женщинами. Кроме того, выявлены четкие генетические различия между ярыми курильщиками и теми, кто легко избавляется от вредной страсти. В последнее время у заядлых курильщиков выявлена группа генов, локализованных в хромосоме 15 (15q24). Эти гены (CHRNA5, CHRNA3, CHRNB4), а также ген CHRNA4, локализованный в хромосоме 20 (20q13.33), кодирующих протеины, входят в состав рецепторов нейротрансмиттера ацетилхолина. Никотин, как составляющая табачного дыма способен имитировать действие ацетилхолина, поэтому ацетилхолиновые рецепторы называются никотиновыми. Связывая молекулы никотина с рецепторами нервных клеток, эти протеины вызывают никотиновую зависимость. Кроме того, к развитию никотиновой зависимости причастны гены, кодирующие ферменты метаболизма других нейротрансмиттеров - DRD2 (11q23.2), DAT1(SLC6A3) (5p15.3), COMT (22q11.21), MAOA (Xp11.2) далее, а также ген фермента СYР2A6 (19q13.2), который принимает участие в нейтрализации ядовитых веществ. Исследования показали, что полиморфизм ADH2 имеет защитный фактор против алкоголизма, и что этот ген более распространен в некоторых этнических группах, чем в других [19].

Наиболее ответственными генами-кандидатами, для которых установлена связь с депрессивным и агрессивным поведением, являются гены транспортеров серотонина 5-HTT, норадреналина NET, нейротропного фактора мозга BDNF, серотониновых рецепторов HTR1A, HTR2A, гены ферментов триптофан гидроксилазы TPH, катехол-О-метилтрасферазы СОМТ, метилентетрагидрафолатредуктазы MTHFR, гены провоспалительных медиаторов IL-6, IL-1beta, ФНО-а, СРБ, гены, участвующие в иммунном ответе PSMB4 и TBX21, редкие варианты гена NKPD1 и др. [20].

Ген СОМТ кодирует синтез фермент акатехол-0-метилтрансферазы, который разрушает дофамин и норадреналин. От работы энзима, в свою очередь, зависит, насколько хорошо человек адаптивен к стрессовым ситуациям. Полиморфизм rs4680 (Val158Met) часто именуют «воин». Обнаружен ряд взаимосвязей между медленно реагирующими полиморфными формами фермента СОМТ и болью. При полиморфном варианте АА, который отражает низкую активность гена, а, следовательно, малые возможности в разрушении нейрогормонов, наблюдается очень высокий уровень дофамина. Действие варианта GG - обратное. Поскольку СОМТ разрушает важнейшие нейромедиаторы, обуславливающие эмоциональный фон, его активность, зависящая от полиморфности гена, оказывает непосредственное влияние на подавления или возбуждения эмоциональной сферы. От активности гена зависит выход или усиленное разрушение гормона удовлетворения и удовольствия - дофамина. Катализ норадреналина, ответственного за быстроту мыслительной деятельности м и реакцию на стресс также обуславливает стрессоустойчивость [21]. Генотип АА отвечает за слабоактивный фермент СОМТ, вследствие чего его носитель проявляет неуравновешенность, склонность к паническим атакам, однако отличается выдающимися интеллектуальными способностями. Люди с генотипом АA обладают хорошо развитой мелкой моторикой, идейностью, но плохо переносят боль, склонны к потере контроля при стрессовых ситуациях, лучше думают, чем действуют, более рефлексивны, понимают и признают свои ошибки, обладают хорошей рабочей памятью и ключевыми когнитивными навыками. Генотип GG обуславливает более активную работу фермента, который быстрее катализирует дофамин в ответственной обработку информации и приятные ощущения лобной доле головного мозга. Активная мутация GG по полиморфизму rs4680 встречается у людей с «боевым складом характера». Носители полиморфизма GG демонстрируют лучшие показатели адаптации к стрессовым ситуациям, более открыты к общению, имеют отличную память. Однако, другая сторона медали обусловлена низким уровнем дофамина, вследствие чего они испытывают в меньшей степени чувство удовлетворения от занятий, более склонны к депрессии, демонстрируют более слабые нейромоторные функции. Большинство людей обладают гетерозиготным промежуточным вариантом GA гена СOMT. Они способны принимать рациональные решения в стрессовых ситуациях, но это не мешает им получать от жизни удовольствие в перерывах между переживанием жизненных проблемами [22].

Ген D3-рецептора дофамина (DRD3) локализуется на длинном плече хромосомы 3 на 3q 13.3. Дофаминовый рецептор D3, кодируемый DRD3, локализован на лимбических участках мозга, которые связаны с когнитивными, эмоциональными и эндокринными функциями. В частности, в норме тиротропин-рилизинг-гормон в левых ядрах таламуса больше, у суицидентов симметрично; в норме норадренергическая активность мозга больше в правом полушарии, тогда как у суицидентов симметрично [23]. Кроме того, у суицидентов снижен уровень бета-эндорфинов в левой префронтальной коре и левом хвостатом ядре, а также выше концентрация серотонина в таламических структурах чем в структурах среднего мозга. За метаболизм вышеупомянутых нейромедиаторов отвечают кроме DRD3 целые плеяды генов синтеза и генов регуляторов. Выявлено более 20 
кандидатних генов, мутации которых могут провоцировать суицидальное поведение: SLC6A4 (17q11.1-q12), HTR2A (13q14-q21), MAOA (Xp11) [24].

Разными авторами были, обнаружены ассоциации полиморфных вариантов ТРН2 человека с клинической депрессией, биполярным аффективным расстройством, суицидом, тревожностью, стрессом, алкоголизмом [25;26]. Синдром дефицита внимания с гиперактивностью (СДВГ) является распространенным расстройством среди детского и подросткового населения. СДВГ является семейным расстройством, и генетические исследования оценивают наследственность в 80-90\%. В исследовании T.W. Park с соавторами изучена связь между генетическим типом и аллелями гена ТPH2 у корейских детей с СДВГ. Это исследование показало, что существует значительная корреляция между частотами rs11179027 аллелей ТРН2 с симптомами СДВГ [27]. Так же Гумеровой О.В., Новокович Ю.С с соавторами был запатентован способ прогнозирования уровня тревожности, на основании генотипирования полиморфных локусов генов триптофангидроксилазы ТРН1 (A218 C) и TPH2 (G 703 T). Сочетание генотипов TPH1 A/A и TPH2T/G определяет высокий уровень тревожности, а сочетаниеTPH1C/СиTPH2G/G-низкий уровень ситуативной тревожности. [28].

По результатам многочисленных исследований оказалось, что 50-70\% случаев преступного поведения определяются генетическими факторами. Среди преступников вообще случается значительное число лиц с психопатиями и различными патологиями, одним из симптомов которых является агрессивность. Кроме того, доказано, что присущая преступникам выраженность признаков поиска новизны, экстраверсия, импульсивность, повышенная возбудимость и ослабление контроля над влечениями и побуждениями, жажда приключений, могут быть вызваны наличием C/T — «аллель 7» гена D4-рецептора дофамина (DRD4), который расположен в коротком плече 11-й хромосомы в области р15.5. Рецептор D4 присутствует в наибольших концентрациях в лимбической системе мозга, связанной с «центрами удовольствия», а также в передней коре мозга, отвечающей за функции мышления [29].

В некоторых случаях достаточно мутации одного гена, чтобы вызвать повышенную агрессивность. Ген МАОА некоторые исследователи считают связанным с отклонениями в поведении, поскольку определенные полиморфизмы гена способствуют возникновению патологической агрессии. Снижение активности гена моно-аминооксидазы А (МАОА), локализирующегося в X-хромосоме (Хр11.3) приводит к накоплению нейромедиатора (серотонина\дофамина). Влияние девиантной принадлежности сверстников было значительно сильнее среди лиц с генотипом МАОА с высокой активностью, чем с генотипом с низкой активностью. Среди мужского пола отмечено большее количество людей с девиациями поведения, что некоторые авторы объясняют локализацией гена МАОА в Х-хромосоме [30]. Полиморфизм МАOA rs909525 отвечает за повышение агрессии и риск суицидального поведения. Более высокая активность фермента снижает агрессивность и улучшает мышление, иногда способствует беспокойству. Женщины и мужчины с Т вариантом склонны к беспокойству, а женщины с ТТ - аутоагрессии. Полиморфизм МАОВ rs1799836 также отвечает за агрессию и злой характер. МАОА разрушает нейромедиаторы (включая серотонин, норадреналин и дофамин), которые, как известно, важны в регуляции импульсивного поведения и зависимости от вознаграждения. Мутантные аллели, унаследованные агрессивными и антисоциальными мужчинами, приводили к недостаточной продукции МАО - фермента, который в свою очередь приводит к большой концентрации нейромедиаторов в крови и неэффективности функционирования, что необходимо для правильного контроля импульсов и вознаграждения в головном мозге. [31]

Моноаминоксидазы А и В (МАОА и МАОВ) являются митохондриальными внешними мембраносвязанными флавопротеинами, которые катализируют окислительное дезаминирование нейромедиаторов и биогенных аминов, их дисфункция может быть вовлечена в патогенез и влиять на клинические фенотипы нервно-психических расстройств [32]. В выборке детей мужского пола Новой Зеландии исследование функционального полиморфизма в гене МАО-А выявило, что жестокое обращение с детьми с генотипом, дающим высокий уровень экспрессии МАО-А, было менее вероятно для развития расстройств поведения в подростковом возрасте или участия в насильственных преступлениях во взрослом возрасте, чем жестокое обращение с детьми с генотипом, дающим низкий уровень экспрессии МАО-А [33]. Молекулярно-генетическое исследование Sadeh et a1. (2010) обнаружили, что психопатические черты были связаны с двумя вариантами полиморфизма гена транспортера серотонина. Считается, что вариант полиморфизма гена изменяет серотониновую систему, хотя точный эффект о передаче серотонина в мозг до конца не ясен. В целом, это исследование показывает, что изменения серотонинергической функции могут создавать риск для асоциального поведения путем повышения уязвимости к экологическому стресcy [34].

Проведенный О.В. Гумеровой с коллегами анализ ассоциаций уровня интеллектуального развития человека показал тесную связь с полиморфными участками гена МАОА [35]. В результате исследования А.С. Крюч- 
ковой с соавторами группы подростков и молодых людей выявлено, что среди полиморфизмов, которые определяют риск агрессивного и враждебного поведения, наибольшую роль играет низкоактивный вариант гена фермента МАОА [31]. В исследовании оппозиционно-вызывающего расстройства (поведенческое расстройство, которое в основном относится к повторяющимся моделям непослушного, вызывающего, негативистского и враждебного поведения по отношению к авторитетным фигурам), проведенном (.H. Wang с коллегами в китайской популяции, была выявлена связь моноаминоксидазы А (МАОА) с поведенческими и психическими расстройствами. Результаты позволили предположить, что варианты генов 5-HTTLPR и MAOA-uVNTR могут способствовать восприимчивости к оппозиционно-вызывающему расстройству. Кроме того, полиморфизм гена MAOA-uVNTR может играть роль в восприимчивости к данной девиации только у детей мужского пола [36].

Дополнительные исследования с использованием генетически обоснованных данных близнецов из Национального лонгитюдного исследования здоровья подростков (Add Health) [37] показывают, что гены рецепторов дофамина (DRD2, DRD4), ген транспорта дофамина (DAT1), ген переноса серотонина (5HTT) и МАОА взаимодействуют с такими социальными условиями, как делинквентное поведение сверстников, материнская привязанность, родительская преступность, семейная вовлеченность, семейное положение, религиозность и даже характеристики соседей, предсказывающие преступность, насилие, членство в банде, нежелание, воздержание, и виктимизацию среди взрослых и юношей. Дофаминовые нейроны субстанции среднего мозга порождают дофаминовый путь, который необходим для моторного обучения и контроля. Показано, что потеря дофамина в этой системе ухудшает нейрональный выход из базальных ганглиев, дофамин влияет на ряд других функций мозга, включая вознаграждение, эмоции, когнитивные способности и память. Новое направление исследований в области генетики показывает, что некоторые люди более чувствительны к воздействию социальных вознаграждений и наказаний из-за генетических вариантов в том, как мозг обрабатывает эти факторы. В частности, лиц с генетическими вариантами, связанными с повышением дофамина (например, DRD2, DRD4) более чувствительны к воздействию награды, и, следовательно, гораздо более вероятно, будут продолжать свое социально-вознаграждаемое поведение по сравнению с лицами, которые не несут в себе эти генетические варианты. Это послужило бы усилению оперантной обусловленности для девиантного или не девиантного поведения индивида с таким генотипом, в зависимости от того, за какое поведение индивид получает социальное вознаграждение [38].
Тирозингидроксилаза (ТН) является важнейшим ферментом биосинтеза катехоламинов, определяет активность нейрохимической системы и индуцируется гормонами стресса, ограничивает скорость ферментов, участвующих в синтезе катехоламинов [39]. В гене DRD2 тирозингидроксилазы (TH) имеются полиморфизмы -241A/G,-141C Ins/Del и Ser311Cуs, полиморфизм Ser9Gly гена DRD3 и полиморфизмы Val81Met гена TH. В анализе японской популяции наблюдалась тенденция ассоциации между тревожностью и полиморфизмом DRD2-141C Ins/Del, а также между тревожностью и DRD2 Ser311Cys. В эпистатическом анализе наблюдалась тенденция к взаимодействию по показателям невротизма и тревожности признаков между полиморфизмами DRD2-141C Ins / Del и TH Val81Met. Однако эти различия были незначительными [40].

DiLalla L.F. \& Bersted K. пришли к выводу, что дети c DRD4-7R были более склонны к негативному внешнему поведению (например, хулиганству, преступности, агрессии) в том случае, если они испытывали внешнее влияние, в то время как дети без аллеля DRD4-7R были менее склонны к негативному внешнему влиянию и девиантному поведению [41]. Эта вариация считается дифференциальной восприимчивостью, которая используется для описания того, когда люди с определенными генами «подвергаются риску» поведения, которое поощряет их окружающая среда.

В исследовании М. Bence с соавторами показано, что дофаминергические пути, которые влияют на настроение и поведение, сильно поражены при церебральной гипоксии. В экспериментах на мышах была изучена гипоксическая чувствительность ключевых дофаминергических генов, в результате чего было показано, что транскрипция постсинаптических дофаминовых рецепторов типа D3 и D4 (DRD3 и DRD4) индуцировалась в несколько раз при 2-дневной гипоксии клеточно-специфическим образом, тогда как ген фактора роста эндотелия сосудов активировался после 3-х дней инкубации при гипоксии. Уровни мРНК дофаминового рецептора типа 2, переносчика дофамина, его метаболических ферментов (моноаминооксидазы (МАО) и катехол-о-метилтрансферазы (СОМТ)) не изменились, в то время как факторы, регулирующие дофаминовый рецептор (DRRF) были снижены гипоксией. Примечательно, что 2-дневная гипоксия не приводила к повышению уровня DRD3 и DRD4, что позволило предположить, что медленно реагирующие чувствительные к гипоксии факторы транскрипции могут быть вовлечены в трансактивацию промоторов DRD3 и DRD4 при гипоксии [42].

Одним из видов девиантного поведения является гомосексуализм - половое влечение к людям своего 
пола. Значительное влияние на формирование гомосексуального поведения имеют факторы окружающей среды, особенно у женщин, о чем свидетельствует средний коэффициент унаследования девиантного сексуальности (51\% мужчин и 26\% для женщин) [43]. Генов сексуальной ориентации у человека пока не обнаружено. Общегеномные секвенирования последних лет показали связь мужской гомосексуальности с локусами в хромосоме 7 (7q36), 8 (8p12), 10 (10q26) и X (Хq28) при условии, если 10-я хромосома, как и X, полученная от матери. Таким образом, оказалось, что, четко наследуется хотя бы один тип мужской гомосексуальности [44].

\section{Зак^ючение}

Подавляющая часть случаев девиантного поведения определяется наследственной предрасположенностью, при которой в развитии расстройства принимают участие мутантные вариации генома. Кроме того, необходимо учитывать сложное взаимодействие между генами и окружающей средой. Генетические влияния при этом могут обостряться в результате определенных пережи- ваний или воздействия определенных обстоятельств. Точно так же индивидуумы с разными генотипами могут по-разному реагировать на то же самое воздействие окружающей среды. Существует связь между функцией головного мозга и девиантным поведением. В частности, рассматривается связь между гипоксией и ее влиянием на структуры головного мозга, отвечающие за поведенческие реакции. Вследствие гипоксии возможны нарушения высшей нервной деятельности, которые проявляются снижением способности адекватно оценивать происходящие события, ощущениями боли и дискомфорта, тяжести в голове, нарушением координацией движений, затруднением логического мышления тяжелых случаях и другими проявлениями. При гипоксии мозга механизмы нейротрансмиссии могут корректироваться и приводить к устойчивым изменениям, которые отражаются на нервных и эмоциональных реакциях и поведении индивидуума. Однако, такие механизмы исследованию поддаются с трудом, поскольку нуждаются в экспериментальных доказательствах. В связи с этим перспективным представляется изучение предрасположенности к формированию девиантного поведения по полиморфным вариантам ряда генов.

\section{ЛИТЕРАТУРА}

1. Hanımoğlu E Deviant Behavior in School Setting. Journal of Education and Training Studies. 2018;6(10).133-141.

2. Куприянова В.М. Девиантное поведение у подростков. Профилактические мероприятия в медицине. Международный студенческий научный вестник. 2018;(5): URL: http://eduherald.ru/ru/article/view?id=19180 (дата обращения: 06.09.2020).

3. Duncan J.R. Current perspectives on the neurobiology of drug addiction: A focus on genetics and factors regulating gene expression. ISRN Neurology. 2012. 972607. 10.5402/2012/972607.

4. Ветош А.Н. Взаимодействие кислородчувствительных механизмов в клетке. Ульяновский медико-биологический журнал. 2019;(3):52-62.

5. Safronova 0. Nobel PRIZE WINNERS in physiology or medicine-W. Kaelin, sir P. Ratcliffe, G.L. Semenza. 2019.12.

6. Аллилуев И.А. Транскрипционный фактор hif-1: механизмы регуляции при гипоксии и нормоксии. Известия высших учебных заведений. Северокавказский регион. Естественные науки. 2014;(5):56-58.

7. Pithadia A.B., Jain S.M. 5-Hydroxytryptamine Receptor Subtypes and their Modulators with Therapeutic Potentials. J Clin Med Res. 2009;1(2):72-80.

8. Ковш Е.М. Обзор современных исследований психогенетических факторов агрессивного поведения. Российский психологический журнал. 2014;11(4):91-101.

9. Vetulani J. Neurochemia impulsywności i agresji [Neurochemistry of impulsiveness and aggression]. Psychiatria Polska. 2013;47(1):103-115.

10. Шустикова М.В. Генетические и средовые детерминанты агрессивного поведения. Вестник Харьковского национального университета им. В.Н. Каразина. Серия: Биология. 2005; 1-2(709):111-115.

11. Nordquist N., Oreland L. Serotonin, genetic variability, behaviour, and psychiatric disorders a review. Ups J Med Sci. 2010;115(1):2-10.

12. Черепкова Е.В. Исследование полиморфизмов ряда генов нейромедиаторной системы головного мозга и опиоидной рецепции у наркотизирующихся. Экспериментальные и клинические исследования. Бюллетень сибирской медицины. 2009;3(2):49-54.

13. Gingrich J.A. \& Caron M.G. Recent advances in the molecular biology of dopamine recep-tors. Annual review of neuroscience 1993. 16(1) 299-321.

14. Cubells J.F. Kranzler H.R. McCance-Katz E. et al. A haplotype at the DBH locus associ-ated with low plasma dopamine p-hydroxylase activity also associates with cocaine-induced para-noia. Mol. Psychiatry. 2000;(5):56-63.

15. Samochowiec J., Samochowiec A., Puls I., Bienkowski P., \& Schott BH Genetics of Alcohol Dependence: A Review of Clinical Studies. Neuropsychobiology, 2014;(70):77-94.

16. Горбунова Е.В. Исследование ассоциаций ряда генов-кандидатов с острым алкогольным психозом: Автореф. дис. .... канд. мед-биол. наук. Уфа. 2002.21.

17. Jung Y., Montel R.A., Shen P.H., Mash D.C., Goldman D. Assessment of the Association of D2 Dopamine Receptor Gene and Reported Allele Frequencies With Alcohol Use Disorders: A Systematic Review and Meta-analysis. JAMA Netw Open. 2019;2(11):1914940.

18. Prevalence of tobacco smoking (2019) World Health Organization Retrieved from https:/wwww.hoint/gho/tobacco/use/en/ 
19. Erzurumluoglu A.M., Liu M., Jackson V.E., et al. Meta-analysis of up to 622,409 individuals identifies 40 novel smoking behaviour associated genetic loci [published online ahead of print, 2019 Jan 7]. Mol Psychiatry. 2019;10-18.

20. Платонкина Т.В. Генетические исследования депрессивных расстройств: обзор литературы Бюллетень физиологии и патологии дыхания 2018;(68):96106.

21. Soldatkin V.A. The MAOA and COMT gene polymorphisms in patients with schizophrenia committed homicide. International Journal Of Biomedicine 2014;4(4)213-217.

22. Булейко А.А. Память внимание мышление больных шизофренией: связь с полом алкоголизацией и полиморфизмом гена катехол-орто-метилтрансферазы. Медицинский вестник Юга России 2017;8(3):23-32.

23. Lu Da, Lu Ting-Ren, Che J. Genetics in Suicide Treatments, Modern Diagnosis Establishments. Journal of Mental Disorders \& Treatment. 2016;(3)145:85-95

24. Соколов П., Гирос Б., Мартр М-П. Молекулярное клонирование и характеристика нового дофаминового рецептора (D-3) в качестве мишени для нейролептиков Nature 1990;(347):146-151.

25. Zill P. Single nucleotide polymorphism and haplotype analysis of a novel tryptophan hydroxylase isoform (TPH2) gene in suicide victims Biol Psychiatry 2004;56(8):581586

26. Harvey M. Polymorphisms in the neuronal isoform of tryptophan hydroxylase 2 are associated with bipolar disorder in French Canadian pedigrees Psychiatr Genet 2007;17(1):17-22.

27. Park T.W. Park Y.H. Kwon H.J. et al. Association between TPH2 gene polymorphisms and attention deficit hyperactivity disorder in Korean children. Genetic testing and molecular biomarkers 174 (2013): 301-6

28. Гумерова 0.В., Горбунова В.Ю., Давыдова Ю.Д., Хафизова Л.М., Новокович Ю.С. Способ прогнозирования уровня тревожности. Патент на изобретение № RU2694230 C1 от 10.07.2019.

29. Ding Y.C., Chi H.C., Grady D.L., Morishima A. Evidence of positive selection acting at the human dopamine receptor D4 gene locus. Proc Natl Acad Sci USA 2002;(99):309-314.

30. Naoi M., Riederer P., Maruyama W. Modulation of monoamine oxidase (MA0) expression in neuropsychiatric disorders: genetic and environmental factors involved in type A MAO expression. Journal of Neural Transmission. 2016;(123):91-106.

31. Крючкова А.С., Ермаков П.Н., Абакумова И.В. Анализ ассоциаций полиморфизма гена МАОА с агрессивными и враждебными стратегиями в поведении у подростков и молодых людей. Российский психологический журнал 2016;13(1):115-124.

32. Fergusson D.M., Boden J.M., Horwood L.J., Miller A.L., Kennedy M.A. MAOA, abuse exposure and antisocial behaviour: 30-year longitudinal study. Br J Psychiatry. 2011;198(6):457-463.

33. Zhao B., Cao Y., Zhang L. and Zhang W Parenting Practices and Adolescent Effortful Control: MA0A T941G Gene Polymorphism as a Moderator. Front. Psychol. 2020;(11):60-62.

34. Sadeh N., Javdani S., Jackson J.J., Reynolds E.K. et al. Serotonin transporter gene associations with psychopathic traits in youth vary as a function of socioeconomic resources Journal ofAbnormal Psychology. 2010;(119):604-609.

35. Гумерова 0.В., Столбова 0.В., Зарипова Т.Ю. Молекулярно-генетический анализ ассоциаций полиморфных маркеров генов нейромедиаторных систем с уровнем интеллектуального развития человека. Вестник Башкирского университета 2007;(1):39-42.

36. Wang C.H., Ning Q.F., Liu CAssociations of serotonin transporter gene promoter polymorphisms and monoamine oxidase a gene polymorphisms with oppositional defiant disorder in a Chinese Han population. Behavioral and Brain Functions 2018;(14):5-8.

37. Udry J.R. The National Longitudinal Study of Adolescent Health (Add Health) Waves I and II 1994-1996; Wave III 2001-2002 [machine-readable data file and documentation] Chapel Hill NC: Carolina Population Center. 2006; 9 (6): 988-97.

38. Hahn T., Heinzel S., Dresler T., Plichta M.M. Association between reward-related activation in the ventral striatum and trait reward sensitivity is moderated by dopamine transporter genotype Human Brain Mapping. 2011;(32):1557-1565.

39. Persson M.L., Wasserman D., Jonsson E.G., Bergman H. Search for the influence of the tyrosine hydroxylase (TCAT)n repeat polymorphism on personality traits. Psychiatr Res. 2000;(95): 1-8.

40. Ishiguro H., Arinami T., Saito T., Akazawa S Systematic search for variations in the tyrosine hydroxylase gene and their associations with schizophrenia, affective disorders, and alcoholism. Am J Med Genet. 1998;(81): 388-396.

41. DiLalla, Lisabeth F. and Bersted K. Biosocial foundations of externalizing behaviors, in The Routledge International Handbook of Biosocial Criminology ed. Matt DeLisi and Michael G. Vaughn (Abingdon: Routledge, 23 дек 2014), Routledge Handbooks Online.

42. Bence M., Kereszturi E., Mózes V. Hypoxia-induced transcription of dopamine D3 and D4 receptors in human neuroblastoma and astrocytoma cells. BMC Neuroscience. 2009;10(1):92-95.

43. Bailey J.M., Dunne M.P., Martin N.G. Genetic and environmental influences on sexual orientation and its correlates in an Australian twin sample. J Pers Soc Psychol. 2000;78(3):524-536.

44. Ngun T.C., Vilain E. The biological basis of human sexual orientation: is there a role for epigenetics? Adv Genet. 2014;(86):167-184.

( Горбунова Валентина Юрьевна ( valentina2075034@mail.ru ), Новокович Юлия Сергеевна ( vorobeva.e.v@bspu.ru ),

Воробьева Елена Владимировна.

Журнал «Современная наука: актуальные проблемы теории и практики» 